\title{
Purification of Protease from Pseudomonas thermaerum GW1 Isolated from Poultry Waste Site
}

\author{
Smriti Gaur, Sarita Agrahari and Neeraj Wadhwa*
}

Department of Biotechnology, Jaypee Institute of Information Technology (Deemed University) A-10, sec 62, Noida, Uttar Pradesh, India

\begin{abstract}
An extracellular protease was purified from Pseudomonas thermaerum GW1 a new strain identified by morphological, biochemical and 16S rDNA sequencing. It was isolated from soil of Poultry waste site at Ghazipur near Ghaziabad, Delhi. The strain produces extra cellular protease in the culture media that was maintained at $37^{\circ} \mathrm{C}, 140 \mathrm{rpm}$. The media was harvested for protease after $48 \mathrm{hrs}$ of incubation at $37^{\circ} \mathrm{C}$ in basal media supplemented with $1 \%$ casein. We report 6.08 fold purification of enzyme following ammonium sulphate precipitation and DEAE-cellulose chromatography. The molecular weight of the enzyme was estimated to be approximately 43,000 daltons as shown by casein zymography studies. The optimum $\mathrm{pH}$ for the proteolytic activity was $\mathrm{pH} 8.0$ and enzyme remained stable between $\mathrm{pH} 5-11$ at $60^{\circ} \mathrm{C}$. Interestingly $\mathrm{Mn}^{2+}(5 \mathrm{mM})$ activated enzyme activity by 5 fold, while $\mathrm{Cu}^{2+}, \mathrm{Mg}^{2+}$ and $\mathrm{Ca}^{2+}$ moderately activated enzyme activity, where as $\mathrm{Zn}^{2+}, \mathrm{Fe}^{2+}$ and $\mathrm{Hg}^{2+}$ inhibited enzyme activity. The protease produced was stable in presence of $50 \%$ (v/v) ethylacetate and acetone. Isopropanol, methanol and benzene increased protease activity by $2.7,1.3$ and 1.1 fold respectively but was inhibited in presence of glycerol and DMSO. This organic solvent-stable protease could be used as a biocatalyst for enzymatic peptide synthesis
\end{abstract}

Keywords: Protease, Pseudomonas, Casein zymography

\section{INTRODUCTION}

Proteases covers up to $60 \%$ of total enzyme market and are valuable commercial enzyme that have biotechnological as well as industrial applications however the present known proteases are not sufficient to meet most of the industrial demands It is desirable to have new proteases with novel properties from different sources. Alkaline proteases hold a great potential for application in the detergent and leather industries [1-3] and are also reported to have been isolated from microbes, plants and animals.

Proteases from plant sources have application in food industry [4]. Previous studies in our lab have shown that proteases from senesced leaves of Lantana camara can have application in detergent industry as the enzyme is thermostable [5]. Microbes are the preferred source of proteases because of their rapid growth, and the ease with which they can be genetically manipulated to generate new enzymes with altered properties [6, 7]. Proteases have been purified and characterized from several bacteria [8-12]. However there are only few reports on Pseudomonas thermaerum, Yang et al., [13] have identified two strains of Psudomonas thermaerum isolated from activated sludge that could use lignin as sole carbon source and excrete peroxidases. A novel antimicrobial peptide $(30 \mathrm{kDa})$ produced by a this bacterium isolated from the effluent pond of a bovine abattoir showed inhibition to a broad range of indicator

*Address correspondence to this author at the Department of Biotechnology, Jaypee Institute of Information Technology (Deemed University) A-10, sec 62, Noida, Uttar Pradesh, India; Tel: + (91)-120-2400973-976;

Fax: + (91)-120-2400986; E-mail: neeraj.wadhwa@jiit.ac.in strains, including pathogenic and food spoilage bacteria such as Listeria monocytogenes, Bacillus cereus, Staphylococcus aureus has been reported by Fontoura et al., [14]. The partially purified antimicrobial substance remained active over a wide temperature range and was resistant to all proteases. S28 strain isolated from Nanyang oil field was identified to be as $P$. thermaerum based on homology studies and could degrade $82.02 \%$ of phenenthrene within 10 days [15].

In our attempt to screen for microbial isolate that can provide stable enzyme, soil sample of the poultry waste site which is rich in organic waste was selected. In this investigation, we report the production and effect of $\mathrm{pH}$, temperature, metal ions and substrate concentration on protease secretion whereby the culture condition were manipulated for maximum protease production. Pseudomonas thermareum GWI was isolated from soil of poultry waste site and it extracellularly secreted this protease which was purified to homogeneity, characterized and found to be stable in the presence of several organic solvents. Ours is the first report that shows extracellular production of proteases from Pseudomonas thermaerum GW1 strain.

\section{MATERIALS AND METHODS}

\section{Isolation and Screening of Protease-Producing Strains}

Soil was collected in sterilized sampling bags of Ghazipur poultry waste site, India. The microbe responsible for the production of protease was identified. The classification was based on gram strain (-), catalase (+) and oxidase $(+)$ reactions, using morphological and biochemical 
characteristics based on Bergey's Manual of Determinative Bacteriology [16]. Soil was selected from areas where naturally degraded feather were seen. The samples were brought to the laboratory and processed for the analysis the same day. Soil samples were suspended in basal media and kept for growth at $37^{\circ} \mathrm{C}$ for 6 days. At regular intervals of 6 hrs the activity of protease was measured and sample showing maximum activity was screened for protease producing strains. Samples of repeated batch cultures were plated on skim milk agar. After $24-48 \mathrm{hrs}$ at $37^{\circ} \mathrm{C}$, colonies which exhibited the largest cleared zones were selected and was further incubated in cultivation media for further $48 \mathrm{hrs}$ and checked for protease production.

\section{Identification of Protease Producing Bacteria}

The isolate GW1 was identified originally as a strain of Pseudomonas by our laboratory based on Morphological, Physical, Biochemical characteristics and the single colony was subcultured on bacterial culture plates supplemented with casein. The culture was sent for identification till species level to Bangalore GeneI India by partial $16 \mathrm{~S}$ r DNA sequence analysis.

\section{Production of Enzyme in Cultivation Media}

The Basal media for protease production composed of $\left(\mathrm{g}^{\mathrm{L}-1}\right.$ ): Peptone, 5; Glucose, $10 ; \mathrm{NaCl}, 0.5 ; \mathrm{CaCl}_{2} 2 \mathrm{H}_{2} \mathrm{O}, 0.1$; $\mathrm{K}_{2} \mathrm{HPO} 4,0.3 ; \mathrm{KH}_{2} \mathrm{PO} 4,0.4 ; \mathrm{MgSO}_{4} \cdot 7 \mathrm{H}_{2} \mathrm{O}, 0.1$; and yeast extract, 5. The $\mathrm{pH}$ was maintained at 7.5. Microbes were allowed to grow in $500 \mathrm{ml}$ conical flask containing $50 \mathrm{ml}$ of the culture media that was maintained at $37^{\circ} \mathrm{C}$ at $140 \mathrm{rpm}$. $5 \%(\mathrm{v} / \mathrm{v})$ of the $20 \mathrm{hrs}$ old culture was inoculated in cultivation media [17].

i Tryptic soy broth (TSB)

ii Gelatin $(1 \%)+$ basal medium for protease production

iii Casein $(1 \%)+$ basal medium for protease production

iv Skim milk powder $(1 \%)+$ basal medium for protease production

$\mathrm{v}$ Pigeon feathers $(1 \%)+$ basal medium for protease production

The above cultivation media were checked for enzyme activity at regular intervals of $6 \mathrm{hrs}$ by the modified method of Tsuchida et al. [18].

\section{Protease Purification}

The bacterial strain was grown for $48 \mathrm{hrs}$ at $37^{\circ} \mathrm{C}$ in the selected cultivation media. The culture medium was centrifuged at $10,000 \mathrm{rpm}$ for $10 \mathrm{~min}$ at $4{ }^{\circ} \mathrm{C}$ and the cell-free supernatant was precipitated with $0-60 \%$ ammonium sulfate. The precipitate was collected by centrifugation and dissolved in a small volume (1/50) of $10 \mathrm{mM}$ Tris- $\mathrm{HCl}$ buffer ( $\mathrm{pH} 8.0$ ), and dialyzed against 4 liters of same buffer for $12 \mathrm{hrs}$ at $4{ }^{\circ} \mathrm{C}$. This step was repeated twice. The dialyzed enzyme preparation was applied on a DEAE-cellulose column $(2 \times 24 \mathrm{~cm})$ pre-equilibrated with $10 \mathrm{mM}$ Tris- $\mathrm{HCl}(\mathrm{pH} 8.0)$. The unadsorbed protein fraction was eluted with the same buffer ( 150 $\mathrm{ml}$ ). The enzyme was eluted with a gradient of $2 \mathrm{mM}$ and 4
$\mathrm{mM} \mathrm{NaCl}$ in the same buffer at a flow rate of $1 \mathrm{ml} / \mathrm{min}$. Active fractions that contained (80\%) of the enzyme activity were pooled, and subsequently used for characterization. All steps were conducted at $4^{\circ} \mathrm{C}$.

\section{Determination of Protease Activity}

Protease activity was assayed by a modified method of Tsuchida et al. [18] by using casein as substrate. $100 \mu 1$ of enzyme solution was added to $900 \mu \mathrm{l}$ of substrate solution (2 $\mathrm{mg} / \mathrm{ml}(\mathrm{w} / \mathrm{v})$ casein in $10 \mathrm{mM}$ Tris- $\mathrm{HCl}$ buffer, $\mathrm{pH}$ 8.0). The mixture was incubated at $45^{\circ} \mathrm{C}$ for $30 \mathrm{~min}$. Reaction was terminated by the addition of an equal volume of $10 \%(\mathrm{w} / \mathrm{v})$ chilled trichloroacetic acid then the reaction mixture was allowed to stand in ice for $15 \mathrm{~min}$ to precipitate the insoluble proteins. The supernatant was separated by centrifugation at $10,000 \mathrm{rpm}$ for $10 \mathrm{~min}$ at $4^{\circ} \mathrm{C}$; the acid soluble product in the supernatant was neutralized with $5 \mathrm{ml}$ of $0.5 \mathrm{M} \mathrm{Na}_{2} \mathrm{CO}_{3}$ solution. The colour developed after adding $0.5 \mathrm{ml}$ of 3-folddiluted Folin-Ciocalteau reagent was measured at $660 \mathrm{~nm}$. All assays were done in triplicate. One protease unit is defined as the amount of enzyme that releases $1 \mu \mathrm{g}$ of tyrosine per $\mathrm{ml}$ per minute under the above assay conditions. The specific activity is expressed in the units of enzyme activity per milligram of protein.

\section{Protein Concentration}

Protein concentration was determined by the method of Bradford [19] with bovine serum albumin as standard.

\section{Polyacrylamide Gel Electrophoresis and Zymogram}

SDS-PAGE was performed on a slab gel containing $10 \%$ $(w / v)$ polyacrylamide by the method of Laemmli [20]. Casein zymography was performed in polyacrylamide slab gels containing SDS and casein $(0.12 \% \mathrm{w} / \mathrm{v})$ as copolymerized substrate, as described by Choi et al., [21]. After electrophoresis, the gel was incubated for 30 minutes at room temperature on a gel rocker in $50 \mathrm{mM}$ Tris- $\mathrm{Cl}(\mathrm{pH}$ 7.4), which contained $2.5 \%$ Triton X-100 to remove SDS. The gel was then incubated in a zymogram reaction buffer (30 mM Tris-HCl, $\mathrm{pH} 7.4,200 \mathrm{mM} \mathrm{NaCl}$ and $10 \mathrm{mM} \mathrm{CaCl}_{2}$ ) left at $37^{\circ} \mathrm{C}$ for $12 \mathrm{hrs}$ on rocker shaker.The gel was stained with Coomassie brilliant blue $(0.5 \% \mathrm{w} / \mathrm{v})$ for $30 \mathrm{~min}$. The activity band was observed as a clear colourless area depleted of casein in the gel against the blue background when destained in $10 \%$ methanol and $5 \%$ acetic acid for a limited period of time.

\section{Effect of pH on Enzyme Activity}

Effect of $\mathrm{pH}$ on the purified enzyme activity was measured at various $\mathrm{pH}$ ranges $(3.0-12)$. Reaction mixtures were incubated at $45^{\circ} \mathrm{C}$ for $30 \mathrm{~min}$ and the activity of the enzyme was measured as described previously.

\section{Effect Of Temperature On Enzyme Activity And Stability}

The activity of the enzyme was determined by incubating the reaction mixture at different temperatures ranging from $20,30,40,50,60,70$ and $80^{\circ} \mathrm{C}$ were studied. The activity of the enzyme was measured as described previously. 


\section{Effect of Various Metal Ions on Protease Activity}

The effects of metal ions on enzyme activity (e.g., $\mathrm{Ca}^{2+}, \mathrm{Mg}^{2+}, \mathrm{Fe}^{2+}, \mathrm{Mn}^{2+}, \mathrm{Zn}^{2+}, \mathrm{Hg}^{2+}$, and $\mathrm{Cu}^{2+}[5 \mathrm{mM}]$ ) were investigated by adding them to the reaction mixture and pre-incubated for $30 \mathrm{~min}$ at $45^{\circ} \mathrm{C} \mathrm{pH} 10.0$. The activity of the enzyme was measured as described previously.

\section{Effect of Organic Solvents on the Protease Stability}

The organic solvents used were Methanol, Ethyl acetate, Benzene, Glycerol, Sucrose, Toluene, Acetone, Hexane, DMSO, Isopropanol and Ethanol. In the stability test, 1.0 $\mathrm{ml}$ of organic solvent $(100 \% \mathrm{v} / \mathrm{v})$ was added to $1 \mathrm{ml}$ of the reaction mixture and pre incubated at $37^{\circ} \mathrm{C}$ for $30 \mathrm{~min}$. The remaining proteolytic activity was measured as described previously. Stability was expressed as the remaining proteolytic activity relative to the solvent-free controls $(0 \%, \mathrm{v} / \mathrm{v})$.

\section{RESULTS AND DISCUSSION}

\section{Isolation and Identification of Protease-Producing Bacterial Strains}

Soil samples were analyzed for isolation of proteolytic bacterial cultures. Screening of microorganisms that produced protease was done on cultures isolated from soil of Ghazipur poultry waste site. Organic waste such as feathers and other poultry waste is essentially composed of proteins. Protease producing strains were selected by growth on skim milk agar, as described in Methods. Among the cultures tested, the laboratory isolate GW1 showed highest zone of clearance. The purity of the isolated bacteria was ascertained through repeated streaking (Fig not shown).

Microscopic observation of the isolate showed a non sporulating gram negative rods, the bacterium grew aerobically and formed typical blue green, flat, large, grape like odour colonies. The strain showed positive reaction for catalase, oxidase, citrate, nitrate, motility, and production of pyoveridin and pyocyanin. Negative reactions were observed for indole, urea and starch hydrolysis (Table 1). These phenotypic characteristics based on Bergey's Manual of Determinative Bacteriology [16] suggest the Pseudomonadaceae family genus Pseudomonas.

\section{Strain Identification by $16 S$ rDNA Sequencing}

The GW1 strain was identified to be as Pseudomonas thermaerum as predicted by $16 \mathrm{~S}$ rDNA studies. Studying the Alignment view of the sequence of the isolated microbe using combination of NCBI GenBank and RDP database using 10 examples and nucleotide similarity. Nearest homolog was found to be Pseudomonas aeruginosa strain EKi (Accession No. FJ685995). The details are given in Table 2, 3 respectively.

The sequence of the isolate GW1 was submitted to the GenBank (Accession Number GU951516)" and based on nucleotide homology and phylogenetic analysis it is found to have close similarity to Pseudomonas thermaerum strain EKi (GenBank Accession Number: F3816019) (Fig. 1).

\section{Protease Production and Effects of Different Parameters}

Protease production was tested at various time interval (1-7 days) and influence of addition of various nutrient sources (TSB, Gelatin, Casein, Skim milk, Pigeon feathers) were evaluated in relation to enzyme yield. Pseudomonas thermaerum strain GW1 grew in five nutrient sources and produced protease. The highest protease production 32 units/mg occurred in Basal medium supplemented with casein whereas lowest in basal medium supplemented with Pigeon feathers 9.7 units $/ \mathrm{mg}$ protein after $48 \mathrm{hrs}$ of cultivation (Fig. 2).

Table 1. Morphological and Biochemical Characteristics of Isolate

\begin{tabular}{|l|l|}
\hline $\begin{array}{l}\text { Morphological and Biochemical } \\
\text { Characteristics }\end{array}$ & Results \\
\hline \hline Colony morphology & Irregular,Undulated,slimy and flat \\
\hline Pigment & Light green to blue green \\
\hline Texture & Shiny, smooth \\
\hline Odour & Sweet grapey \\
\hline Gram staining & Gram Negative rods \\
\hline Spores & - \\
\hline Aerobic growth & + \\
\hline Motility & + \\
\hline Catalase & + \\
\hline Oxidase & + \\
\hline Glucose & - \\
\hline Lactose & - \\
\hline Sucrose & - \\
\hline Methyl Red & - \\
\hline V-P test & - \\
\hline Indole & - \\
\hline Citrate & - \\
\hline Nitrate reduction & - \\
\hline Urea Test & - \\
\hline Starch Hydrolysis & - \\
\hline Pseudomonas agar P & - \\
\hline Cetrimide Agar & \\
\hline Identification of organism & \\
\hline
\end{tabular}

\section{Purification of Protease}

The extracellular protease produced by Pseudomonas thermaerum strain $\mathrm{GW} 1$ was purified in two steps by $0-60 \%$ 
Table 2. Table gives the Alignment view of the Sequence of the Isolated Microbe Using Combination of NCBI GenBank and RDP Database Using 10 Examples. Nearest Homolog was Found to be Pseudomonas Aeruginosa Strain EK1 (Accession No. FJ685995)

\begin{tabular}{|c|c|c|c|}
\hline$\square$ & PGW1B & 0.81 & Studied sample \\
\hline 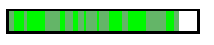 & FJ685995 & 0.83 & Pseudomonas aeruginosa strain EK1 \\
\hline $\begin{aligned}-2 \\
\end{aligned}$ & FJ864676 & 0.99 & Pseudomonas aeruginosa strain ppla \\
\hline$\square$ & EU352760 & 1.00 & Pseudomonas aeruginosa strain NK $2.1 B-1$ \\
\hline 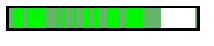 & EU331416 & 1.00 & Pseudomonas aeruginosa strain pY11T-3-1 \\
\hline$\square$ & EU099381 & 0.99 & Pseudomonas sp.J16 \\
\hline$\square$ & EF551040 & 0.93 & Pseudomonas sp. GZ1 \\
\hline
\end{tabular}

Table 3. Indicates Nucleotide Similarity (Above Diagonal) and Distance (Below Diagonal) Identities Between the Studied Sample 'PGW1B' and Ten other Closest Homologs Microbe

\begin{tabular}{|c|c|c|c|c|c|c|c|c|c|c|c|c|}
\hline \multicolumn{13}{|c|}{ Distance Matrix } \\
\hline & & 1 & 2 & 3 & 4 & 5 & 6 & 7 & 8 & 9 & 10 & 11 \\
\hline FJ948174 & 1 & --- & 0.996 & 0.949 & 0.999 & 0.999 & 1 & 0.949 & 0.999 & 0.960 & 0.996 & 0.940 \\
\hline EU331416 & 2 & 0.004 & --- & 0.944 & 0.995 & 0.995 & 0.996 & 0.944 & 0.996 & 0.955 & 1 & 0.936 \\
\hline FJ685995 & 3 & 0.051 & 0.056 & --- & 0.948 & 0.949 & 0.949 & 1 & 0.948 & 0.906 & 0.944 & 0.982 \\
\hline EU099381 & 4 & 0.001 & 0.005 & 0.052 & --- & 0.999 & 0.999 & 0.948 & 0.999 & 0.959 & 0.995 & 0.939 \\
\hline FJ864676 & 5 & 0.001 & 0.005 & 0.051 & 0.002 & --- & 0.999 & 0.949 & 0.999 & 0.959 & 0.995 & 0.940 \\
\hline AB305018 & 6 & 0.000 & 0.004 & 0.051 & 0.001 & 0.001 & --- & 0.949 & 0.999 & 0.960 & 0.996 & 0.940 \\
\hline FJ816019 & 7 & 0.051 & 0.056 & 0.000 & 0.052 & 0.051 & 0.051 & --- & 0.948 & 0.906 & 0.944 & 0.982 \\
\hline EU603683 & 8 & 0.001 & 0.004 & 0.052 & 0.002 & 0.002 & 0.001 & 0.052 & --- & 0.959 & 0.996 & 0.940 \\
\hline EF551040 & 9 & 0.041 & 0.045 & 0.094 & 0.041 & 0.041 & 0.041 & 0.094 & 0.041 & --- & 0.955 & 0.894 \\
\hline EU352760 & 10 & 0.004 & 0.000 & 0.056 & 0.005 & 0.005 & 0.004 & 0.056 & 0.004 & 0.045 & --- & 0.936 \\
\hline PGW1B & 11 & 0.060 & 0.064 & 0.018 & 0.061 & 0.060 & 0.060 & 0.018 & 0.060 & 0.106 & 0.064 & --- \\
\hline
\end{tabular}

ammonium sulphate precipitation followed by anion exchange chromatography on DEAE- cellulose resin (Fig. 3). The recovered active fraction from 0-60\% ammonium sulphate of culture broth was adsorbed on the DEAE- cellulose matrix. The bound protease was eluted with 0.2 and $0.4 \mathrm{M} \mathrm{NaCl}$ (in $10 \mathrm{mM}$ Tris- $\mathrm{HCl}$ buffer, $\mathrm{pH}$ 8.0). The protease was purified 6.08 fold and about $9.3 \%$ of the total activity units was recovered. The specific activity of the purified enzyme was 137.54 units/mg. The purified enzyme could be stored in $10 \mathrm{mM}$ Tris- $\mathrm{HCl}$ buffer, $\mathrm{pH} 8.0$, at $-80^{\circ} \mathrm{C}$ for 3 months without any apparent loss of activity. The results of purification of protease from Pseudomonas thermaerum strain GW1 are summarized in Table 4.

\section{SDS-PAGE and Zymogram Analysis}

The DEAE fraction was analysed on SDS PAGE (10\%), showed presence of single band indicating a homogeneous 


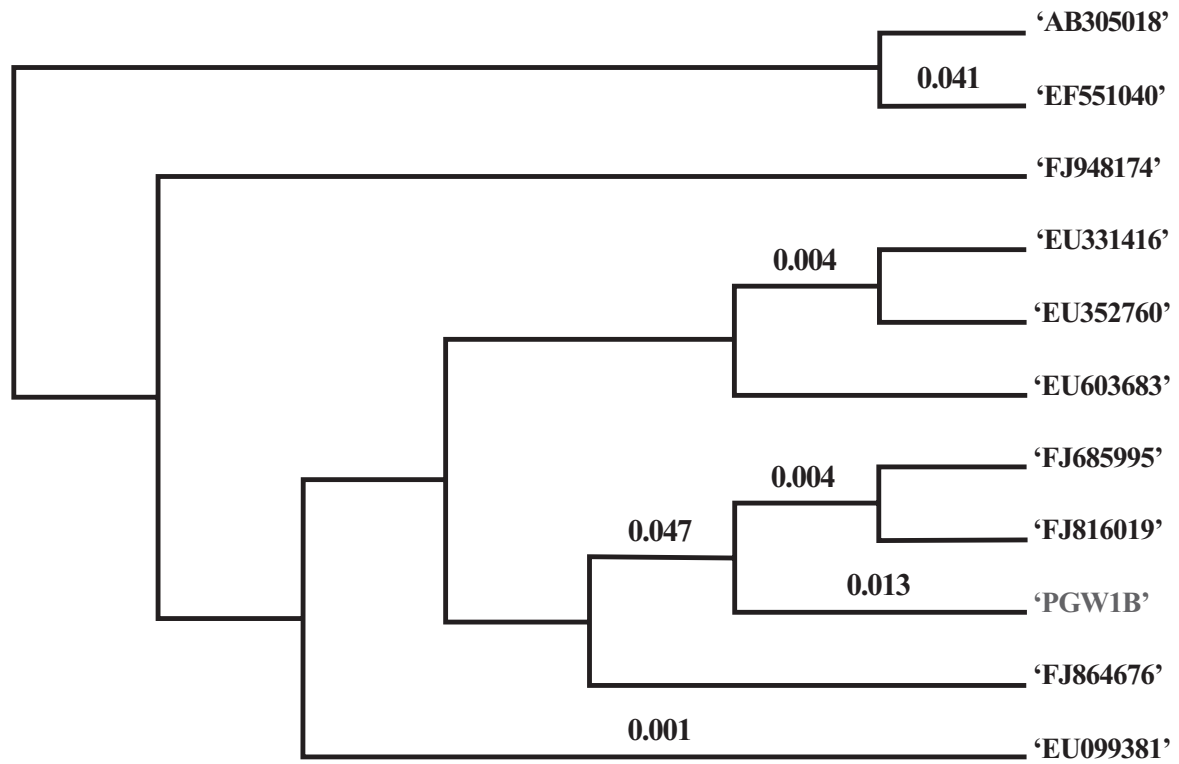

Fig. (1). Phylogenetic tree made in MEGA 3.1 software using neighbor joining method.

preparation. The enzyme has a low molecular weight of approximately 43Kda (Fig. 4 Lane 2). Zymogram activity staining also revealed one clear zone of proteolytic activity against the blue background for purified sample at corresponding positions in SDS-PAGE (Fig. 4 Lane 3).

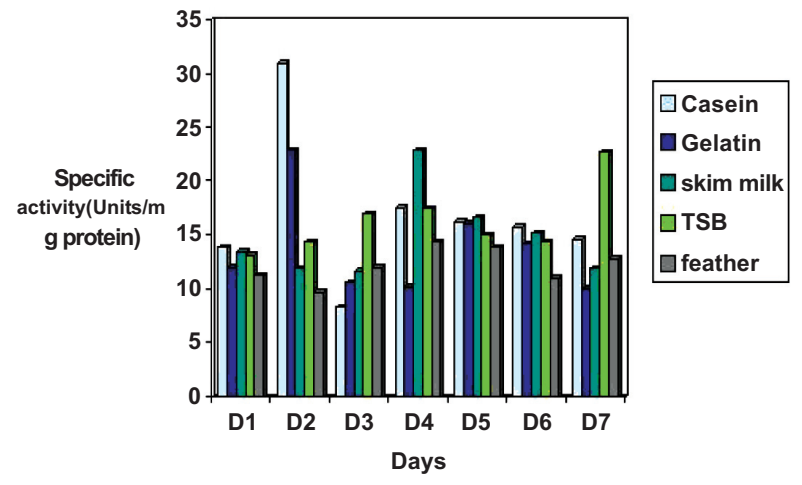

Fig. (2). Study of effect of various nutrient sources on protease production by Pseudomonas thermaerum GW1. The culture was grown for production of protease as described in "Methods". $1 \%$ of the above mentioned nutrient sources were added to basal media. $\mathrm{pH}$ of the media was adjusted to 7.5 .

\section{pH Optimum and pH Stability}

Activity of the enzyme was determined at different $\mathrm{pH}$ ranging from 3.0-12.0. The optimum $\mathrm{pH}$ recorded was 8.0 for protease activity. Protease activity was found to be stable in the alkaline range starting from the $\mathrm{pH} 5-11$ at $45^{\circ} \mathrm{C}$ (Fig. 5).

\section{Temperature Optimum and Thermal Stability}

The thermal stability of the enzyme was also tested at different temperatures $20^{\circ} \mathrm{C}, 30^{\circ} \mathrm{C}, 40^{\circ} \mathrm{C}, 50^{\circ} \mathrm{C}, 60^{\circ} \mathrm{C}, 70^{\circ} \mathrm{C}$ and $80^{\circ} \mathrm{C}$ on incubation for 60 minutes (Fig. 6). The opti- mum temperature recorded was at $60^{\circ} \mathrm{C}$ for protease activity and Protease activity was found to be stable in the temperature range from $40^{\circ} \mathrm{C}-70^{\circ} \mathrm{C}$. The enzyme activity gradually declined at temperatures beyond $70^{\circ}$.

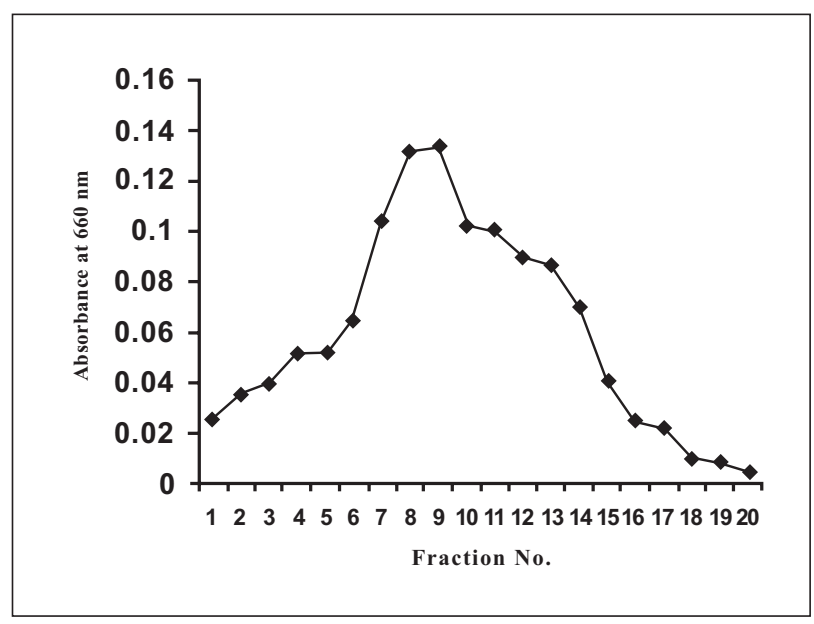

Fig. (3). The bound protease on DEAE column was eluted with 0.2 and $0.4 \mathrm{M} \mathrm{NaCl}$ (in $10 \mathrm{mM}$ Tris- $\mathrm{HCl}$ buffer, $\mathrm{pH}$ 8.0) Fraction of $0.4 \mathrm{M} \mathrm{NaCl}$ showed a single peak of caseinase activity.

\section{Effect of Metal Ions}

$\mathrm{Fe}^{2^{+}}$has a strong inhibitory effect, whereas $\mathrm{Zn}^{2^{+}}$and $\mathrm{Hg}^{2^{+}}$ have mild effects on protease activity. Interestingly $\mathrm{Mn}^{2+}$ strongly activated enzyme activity by 5 fold (Table 5).

\section{Effect of Organic Solvents on the Protease Stability}

Ten organic solvents were used to study the effect on protease activity. As shown in (Fig. 7) the protease has ability to act in the presence of solvents in reaction system. The enzyme retained $78 \%$ and $75 \%$ of activity in the presence of ethylacetate and acetone respectively. The presence of isopropanol, methanol and benzene increased the activity of isolates GW1 by 2.7, 1.3 and 1.1 fold, respectively. 
Table 4. Summary of Purification Steps of Alkaline Protease from Pseudomonas thermaerum

\begin{tabular}{|l|c|c|c|c|c|}
\hline Purification Step & Total Protein(mg) & Total Enzyme Activity(U) & Specific Activity(U/mg) & \% Recovery & Purification Fold \\
\hline \hline Culture supernatant & 117.4 & 2645 & 22.6 & 100 & 1 \\
\hline $\begin{array}{l}\left(\mathrm{NH}_{4}\right)_{2} \mathrm{SO}_{4} \text { Precipitation, } \\
\text { dialyzed (0-60\%) }\end{array}$ & 36.70 & 1940.40 & 52.87 & 73.3 & 2.33 \\
\hline DEAE-cellulose & 1.79 & 246.15 & 137.54 & 9.3 & 6.08 \\
\hline
\end{tabular}

Enzyme lost $60 \%$ of total activity in presence of DMSO and hexane and was not stable in the presence of glycerol, toluene and sucrose. Ogino et al., [22] have reported importance of disulfide bonds for stability of the protein in presence of solvents. Jorden et al., [23] have reported that $61 \%$ of the activity of HIV1 protease was lost in presence of $12 \%$ $\mathrm{Me}_{2} \mathrm{SO}$; similar results were also reported from protease thrombin [24]. This loss of hydrolytic activity over time as reported by the authors is not due to slow dissociation of enzyme dimer into inactive monomer. The activity of HIV1 is also sensitive to glycerol and the hydrolytic efficiency of this enzyme decreases with the increasing concentration of glycerol.

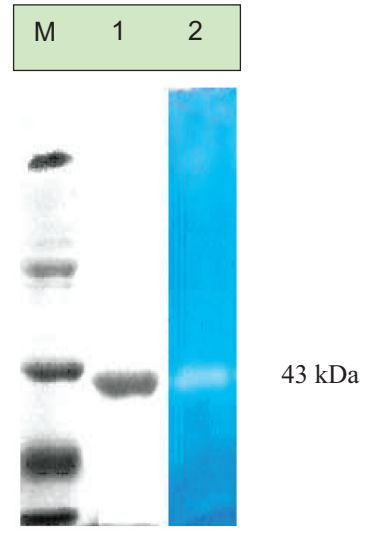

Fig. (4). Acitvity gel electrophoresis of the purified protease, M: molecular weight markers, Lane 1: purified protease on $10 \%$ SDSPAGE and Lane 2: Zymography of purified protease from Pseudomonas thermaerumGW1. Zymography was done by the method of Choi et al.

Table 6 reveals that if the concentration of glycerol is as low as $10 \% \mathrm{v} / \mathrm{v}$. then there is $38 \%$ decrease in Protease activity whereas $45 \%$ decrease in enzyme activity is reported in presence of $20 \% \mathrm{v} / \mathrm{v}$ glycerol.

Ours is the first report that shows extracellular production of proteases from Pseudomonas thermaerum. Protease from GW1 strain lost its activity in the presence of glycerol, sucrose and metal ion iron.

\section{CONCLUSIONS}

Enzyme activity from Pseudomonas thermaerum is lost in the presence of glycerol and sucrose. The buffer best suited for Pseudomonas thermaerum protease should minimize the use of glycerol and sucrose during dialysis.

So far, several well-known proteases such as thermolysin, papain, and chymotrypsin have been used as biocata- lysts of peptide synthesis in the presence of organic solvents. Protease from Pseudomonas thermaerum retained its activity in organic solvents; these results are in line with many studies that report protease stability in the presence of organic solvents [25-29] promising potential industrial application of protease from Pseudomonas thermaerum.

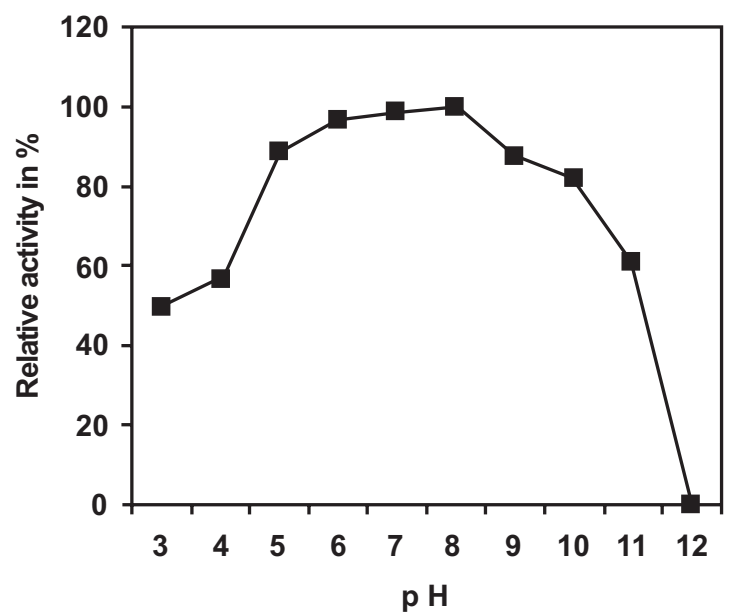

Fig. (5). Effect of $\mathrm{pH}$ on the activity of the purified Protease from Pseudomonas thermaerum GW1 pH optima was measured by incubating the enzyme with the substrate at different $\mathrm{pH}$ values at $45^{\circ} \mathrm{C}$. The maximum activity obtained at $\mathrm{pH} 8.0$ was considered as $100 \%$ activity. The treated enzyme solution was cooled rapidly in ice and the relative activity was measured under standard condition.

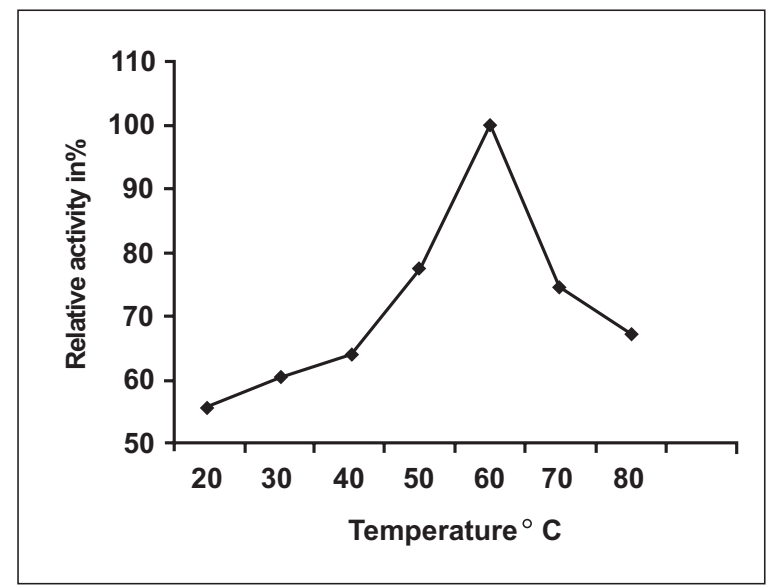

Fig. (6). Effect of temperature on protease activity from Pseudomonas thermaerum $\boldsymbol{G W 1}$. The relative activity was defined as the percentage of activity detected with respect to the maximum protease activity. The maximum activity obtained at temperature $60^{\circ} \mathrm{C}$ was considered as $100 \%$ activity. The treated enzyme solution was cooled rapidly in ice and the relative activity was measured under standard condition. 
Table 5. Enzyme was Incubated with Various Metal Ions at $45^{\circ} \mathrm{C}$ for $30 \mathrm{Min}$

\begin{tabular}{|c|c|}
\hline Metal Ion (5 mM) & Relative protease Activity (\%) \\
\hline \hline Control & 100 \\
$\mathrm{CuSO}_{4}$ & 109.57 \\
$\mathrm{MnSO}_{4}$ & 546.80 \\
$\mathrm{HgCl}_{2}$ & 69.14 \\
$\mathrm{FeCl}_{3}$ & 1.0 \\
$\mathrm{CaCl}_{2}$ & 126.59 \\
$\mathrm{MgCl}_{2}$ & 174.46 \\
$\mathrm{ZnSO}_{4}$ & 80.85 \\
\hline
\end{tabular}

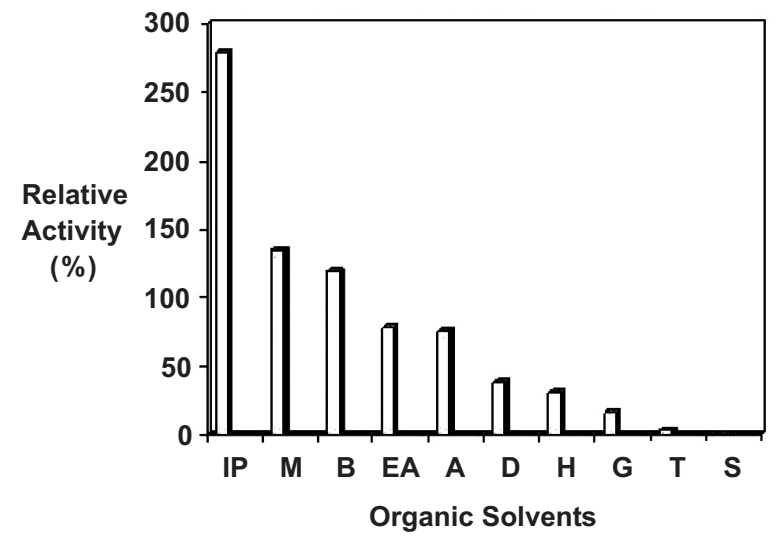

Fig. (7). Figure denotes Influence of different solvents on activity of the purified protease from Pseudomonas thermaerum GW1: purified enzyme $(10 \mu \mathrm{g})$ was preincubated with $100 \% \mathrm{v} / \mathrm{v}$ of various solvents vis Isopropanol (IP), Methanol (M), Benzene (B), Ethylacetate (EA), Acetone (A), DMSO (D), Hexane (H), Glycerol (G), Toluene (T), Sucrose (S) at $37^{\circ} \mathrm{C}$ for 30 minutes. The control (without organic solvent) and treated enzyme solution was cooled rapidly in ice and the relative activity was measured under standard condition as described in methods. Note: the relative enzyme activity of control fraction without organic solvent $(0 \% \mathrm{v} / \mathrm{v})$ was denoted as $100 \%$ The relative activity of treated fractions was defined as the percentage of activity detected with respect to the control fraction.

Table 6. Stability of Enzyme in the Presence of Glycerol

\begin{tabular}{|c|c|}
\hline Glycerol (\%) & Relative Protease Activity (\%) \\
\hline \hline Control (without glycerol) & 100 \\
\hline 10 & 62.6 \\
\hline 20 & 55.2 \\
\hline 40 & 25.2 \\
\hline 60 & 23.9 \\
\hline 80 & 17.3 \\
\hline 100 & 0 \\
\hline
\end{tabular}

\section{ACKNOWLEDGMENT}

We are thankful to Department of Biotechnology, Jaypee Institute of Information Technology (Deemed University) Noida, India for providing infrastructure facilities for this study.

\section{REFERENCES}

[1] Gupta R, Beg QK, Lorenz P. Bacterial alkaline proteases: molecular approaches and industrial applications. Appl Microbiol Biotechnol 2002; 59:15-32.

[2] Kumar CG, Takagi H. Microbial alkaline proteases: from bioindustrial viewpoint. Biotechnol Adv 1999; 17: 561-94.

[3] Oberoi R, Beg QK, Puri S, Saxena RK, Gupta R. Characterization and wash performance analysis of an SDS-resistant alkaline protease from a Bacillus sp. World J Microbiol Biotechnol 2001; 17: 493-97.

[4] Tomar R, Kumar R, Jagannadham MV. A Stable Serine Protease, Wrightin, from the Latex of the Plant Wrightia tinctoria (Roxb.) R. Br.: Purification and Biochemical Properties. J Agric Food Chem 2008; 56:1479-87.

[5] Gaur S, Wadhwa N. Alkaline protease from senesced leaves of invasive weed Lantana camara. Afr J Biotechnol 2008; 24: 4602-8.

[6] Rao MB, Tanksale AM, Ghatge MS, Deshpande VV. Molecular and biotechnological aspects of microbial proteases. Microbiol Mol Biol Rev 1998; 62: 597-635

[7] Fang Y, Liu S, Wang S, Lv M. Isolation and screening of a novel extracellular organic solvent-stable protease producer. Biochem Eng J 2008; 43: 212-5.

[8] Karbalaei-Heidari HR, Ziaee A-A, Schaller J, Amoozegar MA. Purification and characterization of an extracellular haloalkaline protease produced by the moderately halophilic bacterium, Salinivibrio sp. strain AF-2004. Enzyme Microb Technol 2007; 40: 266-72.

[9] Min Z, Cong Z, Xiang D, Ping LF, Chen G. Expression, purification, and characterization of a thermophilic neutral protease from Bacillus stearothermophilus in Bacillus subtilis. Sci China C Life Sci 2008; 51: 52-9.

[10] Abidi F, Limam F, Marzouki MN. Purification and characterization of an alkaline protease prot 1 from botrytis cinerea. Appl Biochem Biotechnol 2007; 141: 361-76.

[11] Sarin R, Mishra P. Purification and characterization of organic solvent stable protease from Bacillus licheniformis RSP-09-37 Appl Microbiol Biotechnol 2008; 79: 399-405.

[12] Jellouli K, Bayoudh A, Manni L, Agrebi R, Nasri M. Purification, biochemical and molecular characterization of a metalloprotease from Pseudomonas aeruginosa MN7 grown on shrimp wastes. Appl Microbiol Biotechnol 2008; 79: 989-99.

[13] Yang JS, Liu W, Ni JR. Isolation, identification of lignin-degrading bacteria and purification of lignin peroxidase. Huan Jing Ke Xue 2006; 27: 981-5.

[14] Fontoura R, Spada JC, Silveira ST, Tsai SM, Brandelli A. Purification and characterization of an antimicrobial peptide produced by Pseudomonas sp. strain 4B. World J Microbiol Biotechnol 2009; 25: 205-13.

[15] Aitken M.D, Stringfellow WT, Nagel RD, Kazunga C, Chen SH. Characteristics of phenanthrene-degrading bacteria isolated from soils contaminated with polycyclic aromatic hydrocarbons. Can J Microbiol 1998; 44: 743-52.

[16] Holt JG, Krieg NR, Sneath PHA, Stately JT, Williams ST. Bergey's manual of determinative bacteriology. $9^{\text {th }}$ ed. Williams and Wilkins: Baltimore 1994.

[17] Miller JH. Experiments in Moleculer Genetics. Cold Spring Harbor Laboratory, Cold Spring Harbor, NY 1972; pp. 431-5.

[18] Tsuchida O, Yamagota Y, Ishizuka J, et al. An alkaline proteinase of an alkalophilic Bacillussp. Curr Microbiol 1986; 14: 7-12.

[19] Bradford MM. A rapid and sensitive method for the quantitation of microgram quantities of protein utilizing the principle of proteindye binding. Anal Biochem 1976; 72: 248-54.

[20] Laemmli UK. Cleavage of structural proteins during the assembly of the head of bacteriophage T4. Nature 1970; 227: 680-5.

[21] Choi NS, Yoon KS, Lee JY, Han KY, Kim SH. Comparison of three substrate (casein, fibrin, andgelatin) in zymographic gel. J Biochem Mol Biol 2001; 34: 386-96. 
[22] Ogino H, Uchiho T, Yokoo J, Kobayashi R, Ichise R, Ishikawa H. Role of intermolecular disulfide bonds of the organic solvent-stable PST-01 protease in its organic solvent stability. Appl Environ Microbiol 2001; 67: 942-7.

[23] Jordan SP, Zugay J, Paul L, Darke S, Lawrence C, Kuo SQ. Activity and dimerization of human immunodeficiency virus protease as a function of solvent composition and enzyme concentration. J Biol Chem 1992; 267: 20028-32.

[24] Wasiewski W, Fasco MJ, Martin BM, Detwiler TC, Fenton JW. Thrombin adsorption to surfaces and prevention with polyethylene glycol 6,000. Thromb Res 1976; 8: 881-6.

[25] Gupta MN. Enzyme function in organic solvents. Eur J Biochem 1992; 203:25-32.
[26] Ogino H, Watanabe F, Yamada M, et al. Purification and characterizationof organic solvent-stable protease from organic solvent tolerant Pseudomonas aeruginosa PST-01. J Biosci Bioeng 1999; 87: 61-8.

[27] Gupta A, Roy I, Khare SK, Gupta MN. Purification and characterization of a solvent stable protease from Pseudomonas aeruginosa PseA. J Chromatogr 2005; 1069: 155-61.

[28] Ghorbel B, Sellami KA, Nasri M. Stability studies of protease from Bacillus cereus BG1. Enzyme Microb Technol 2003; 32: 513-8.

[29] Rahman RNZRA, Geok LP, Basri M, Salleh AB. An organic solvent-stable alkaline protease from Pseudomonas aeruginosa strain K: Enzyme purification and characterization. Enzyme Microb Technol 2006; 39:1484-91.

Received: June 07, 2010

Revised: June 22, 2010

Accepted: June 25, 2010

(C) Gaur et al.; Licensee Bentham Open.

This is an open access article licensed under the terms of the Creative Commons Attribution Non-Commercial License (http://creativecommons.org/licenses/ by-nc/3.0/) which permits unrestricted, non-commercial use, distribution and reproduction in any medium, provided the work is properly cited. 